\title{
Susceptibility of black bullhead Ameiurus melas to a panel of ranavirus isolates
}

\author{
F. Gobbo, E. Cappellozza, M. R. Pastore, G. Bovo* \\ Istituto Zooprofilattico Sperimentale delle Venezie, Viale dell'Università, 10-35020 Legnaro, Padova, Italy
}

\begin{abstract}
Ranaviruses are considered a serious threat to lower vertebrates, including fish, amphibians and reptiles. However, epidemiological data on these agents are lacking, and further investigations are needed to understand the role of carriers and to update the list of susceptible hosts. We carried out various experimental infections under controlled conditions to contribute to the current knowledge on the susceptibility of black bullhead Ameiurus melas to European catfish virus $(\mathrm{ECV})$ and other ranaviruses. A panel of 7 ranavirus isolates was used to challenge duplicate groups of $A$. melas juveniles maintained in aquaria supplied with running dechlorinated tap water. The experiments were performed at 15 and $25^{\circ} \mathrm{C}$. The results confirmed the high susceptibility of $A$. melas to ECV infection. Furthermore, a significant mortality associated with the typical signs of systemic viral infections was observed in groups challenged with Epizootic haematopoietic necrosis virus (EHNV) at $25^{\circ} \mathrm{C}$, and to a lesser extent, at $15^{\circ} \mathrm{C}$. No significant mortality was recorded in fish challenged with European sheatfish virus (ESV), Frog virus 3 (FV3), Rana esculenta virus-like (REVlike), Bohle iridovirus (BIV) or short-finned eel virus (SERV).
\end{abstract}

KEY WORDS: Ranavirus - Black bullhead - Epizootic haematopoietic necrosis virus - European catfish virus $\cdot$ European sheatfish virus

Resale or republication not permitted without written consent of the publisher

\section{INTRODUCTION}

To date, iridoviruses and iridovirus-like agents have been detected only in invertebrate and ectothermic vertebrate hosts (Williams et al. 2005). The family Iridoviridae includes 5 different genera: Iridovirus, Chloriridovirus, Ranavirus, Lymphocystivirus and Megalocytivirus (Chinchar et al. 2005). Several viral agents belonging to the genus Ranavirus have been described as a cause of serious systemic disease in fish, amphibians and reptiles (Wolf et al. 1968, Ahne et al. 1989, Moody \& Owens 1994, Jancovich et al. 1997, Bollinger et al. 1999, Cullen \& Owens 2002, Gantress et al. 2003). The high pathogenicity of these agents has been mainly attributed to their tropism for the sub-endothelial and haematopoietic tissues (Gibson-Kueh et al. 2003). According to the International Committee on Taxonomy of Viruses (Fauquet et al. 2005), there are 5 accepted species: Ambystoma tigrinum virus (ATV), Bohle iridovirus (BIV), Epizootic haematopoietic necrosis virus (EHNV), European catfish virus (includ- ing European catfish virus [ECV] and European sheatfish virus [ESV]), Frog virus 3 (FV3) and SanteeCooper ranavirus (including Doctor fish virus [DFV] and Guppy virus 6 [GV6]) (Chinchar et al. 2005). However, the taxonomy of the genus is still being debated, and further studies are needed, particularly with regard to molecular aspects.

In the past 2 decades, serious outbreaks of ranavirus infection have been reported in Europe from several fish species: sheatfish Silurus glanis in Germany (Ahne et al. 1989), black bullhead Ameiurus melas in France (Pozet et al. 1992, Bigarré et al. 2008) and Italy (Bovo et al. 1993), turbot Scopthalmus maximus in Denmark (Bloch \& Larsen 1993), and pike-perch Sander (= Sander) lucioperca in Finland (Tapiovaara et al. 1998). In Italy, another irido-like agent has been isolated from non-symptomatic short-finned eels Anguilla australis imported from New Zealand. Because of its geographic origin, the isolate was preliminarily identified as New Zealand eel virus (NZ-eelV) (Bovo et al. 1999, Bang Jensen et al. 2009), but the name was 
changed to the more appropriate short-finned eel ranavirus (SERV) (Holopainen et al. 2009) to better identify the isolate and avoid future confusion.

In addition to these viral agents isolated from fish, other ranaviruses infecting amphibians have been widely described. Since the late 1980s, amphibian ranaviruses can be considered as endemic in the UK (Cunningham et al. 2008). In North America, ranaviruses have been described since 1996 as causative agents of disease in amphibians (Green et al. 2002), and more recently FV3-like viruses have been detected in wild amphibian populations (Duffus et al. 2008). Unlike these viruses, EHNV and BIV seem to be confined to the Australian continent, where they affect wild redfin (= Eurasian) perch Perca fluviatilis (Langdon et al. 1986) and farmed rainbow trout Oncorhynchus mykiss (Langdon et al. 1988) and, in the case of BIV, the ornate burrowing frog Limnodynastes orantus (Speare \& Smith 1992).

Ranaviruses pose a potential threat to farmed and wild fish, and amphibian populations and amphibian ranaviruses may possibly represent a risk for commercially important farmed fish, as described for BIV (Moody \& Owens 1994). Because of this, increasing attention has been paid to ranaviruses, and many studies have been performed to determine the host range and the pathogenetic mechanisms (Langdon 1989, Moody \& Owens 1994, Nakajima \& Maeno 1998, Bang Jensen et al. 2009). The main objective of the present study was to investigate the susceptibility of the ictalurid catfish, black bullhead Ameiurus melas, to a panel of ranavirus isolates and, in particular, to confirm its susceptibility to ECV infection under controlled conditions. The black bullhead was chosen because of its high susceptibility to ECV in farmed and wild populations (Pozet et al. 1992, Bovo et al. 1993).
The study was performed by bath infection at 2 different temperatures; this method was chosen because horizontal transmission through contaminated water seems to be the most prominent infection route for ranaviruses (Langdon 1989), although oral and vertical transmission cannot be ruled out (Ariel \& Owens 1997, Duffus et al. 2008) and temperature seems to have a strong effect on disease onset (Whittington \& Reddacliff 1995, Watson et al. 1998).

\section{MATERIALS AND METHODS}

Fish. A total of 1400 juvenile black bullhead originating from an apparently ECV-free farm were introduced into the quarantine facility at the Istituto Zooprofilattico Sperimentale delle Venezie. The age of the fish ranged from 3 (Expts 1 and 3) to 6 mo (Expt 2), and the size of the fish ranged from 3.5 (Expts 1 and 3) to $5.0 \mathrm{~g}$ (Expt 2). The fish were gradually acclimatized in different tanks filled with dechlorinated tap water at either 15 or $25^{\circ} \mathrm{C}$. During the quarantine period, the fish population was routinely monitored, and samples were taken for parasitological, bacteriological and virological investigations, in accordance with routine procedures. Virus investigations were performed in accordance with Decision 2001/183/EC (Commission of the European Communities 2001) with minor changes.

Viruses. A panel of 7 ranavirus isolates selected in the framework of the European Union RANA project were used (Table 1). The isolates were provided by the National Veterinary Institute of Denmark. The isolates were replicated in epithelioma papulosum cyprini (EPC) cells grown in Eagle's minimum essential medium (EMEM, Sigma-Aldrich) supplemented with

Table 1. Ranavirus isolates included in this study and their origin

\begin{tabular}{|c|c|c|c|c|}
\hline Virus & Acronym & Original host & Source of the isolate & Literature source \\
\hline $\begin{array}{l}\text { Epizootic haematopoietic } \\
\text { necrosis virus }\end{array}$ & EHNV & Perca fluviatilis & $\begin{array}{l}\text { R. Whittington, University of } \\
\text { Sydney, Australia }\end{array}$ & Langdon et al. (1986) \\
\hline $\begin{array}{l}\text { European catfish virus } \\
\text { (isolate } 24 / 2006 \text { ) }\end{array}$ & $\mathrm{ECV}$ & $\begin{array}{c}\text { Ameiurus melas } \\
\text { formerly Ictalurus melas }\end{array}$ & $\begin{array}{l}\text { G. Bovo, Istituto Zooprofilattico } \\
\text { Sperimentale delle Venezie, Italy }\end{array}$ & Pozet et al. (1992) \\
\hline European sheatfish virus & ESV & Silurus glanis & $\begin{array}{l}\text { W. Ahne, University of Munich, } \\
\text { Germany }\end{array}$ & Ahne et al. (1989) \\
\hline Short-finned eel ranavirus & SERV & Anguilla australis & $\begin{array}{l}\text { G. Bovo, Istituto Zooprofilattico } \\
\text { Sperimentale delle Venezie, Italy }\end{array}$ & Bovo et al. (1999) \\
\hline Rana esculenta virus-like & REV-like & Pelophylax esculentus & $\begin{array}{l}\text { G. Bovo, Istituto Zooprofilattico } \\
\text { Sperimentale delle Venezie, Italy }\end{array}$ & G. Bovo (pers. comm.) \\
\hline Bohle iridovirus & BIV & Lymnodynastes ornatus & $\begin{array}{l}\text { A. Hyatt, Australian Animal Health } \\
\text { Laboratory, Victoria, Australia }\end{array}$ & Speare \& Smith (1992) \\
\hline Frog virus 3 & FV3 & Rana pipiens & $\begin{array}{l}\text { W. Ahne, University of Munich, } \\
\text { Germany }\end{array}$ & Granoff et al. (1966) \\
\hline
\end{tabular}


foetal calf serum (FCS) $(10 \%)$, penicillin $\left(100 \mathrm{IU} \mathrm{ml}^{-1}\right)$, streptomycin $\left(100 \mu \mathrm{g} \mathrm{ml^{-1 }}\right)$, amphotericin B $(0.25 \mu \mathrm{g}$ $\mathrm{ml}^{-1}$ ) and L-glutamine (2 $\left.\mathrm{mM}\right)$, and incubated at $20^{\circ} \mathrm{C}$. When complete cytopathic effect (cpe) appeared, the supernatants were harvested, centrifuged at $4000 \times g$ for $20 \mathrm{~min}$, titrated on the same cell line and stored at $4^{\circ} \mathrm{C}$ until use. Viral titres were calculated by the $50 \%$ end-point method in 10-fold serial dilutions using EPC cells on 96-well microtitre plates and expressed as tissue culture infectious dose $\left(\mathrm{TCID}_{50} \mathrm{ml}^{-1}\right)$. The selected ranaviruses were originally obtained in their 8 to 10 cell culture passage and stored at $4^{\circ} \mathrm{C}$. Each isolate was subcultured 2 to 3 more times before being used for viral challenge. After production, each viral stock was stored for 6 to $8 \mathrm{~d}$ at $4^{\circ} \mathrm{C}$, until the results of the viral titre analysis were available.

Viral challenge. Each ranavirus isolate was used to challenge 2 duplicate groups, each consisting of 30 fish. The reference viral suspensions were diluted to obtain a final viral concentration of $10^{4} \mathrm{TCID}_{50} \mathrm{ml}^{-1}$. The challenge was performed in $10 \mathrm{l}$ tanks for $60 \mathrm{~min}$. During the challenge, airflow supply was provided. Negative controls were managed in the same way as the infected groups, except that EMEM medium was added instead of the cell culture viral supernatant. Following viral challenge, the different groups were moved from the tanks to $50 \mathrm{l}$ aquaria filled with dechlorinated running tap water (at the same temperature as the bath challenge), where they were maintained for an additional $30 \mathrm{~d}$. The challenge trials were performed at 3 different times (Expts 1, 2 and 3), with some small differences concerning the virus isolate batch and fish size. All trials, including the bath challenge and the $30 \mathrm{~d}$ observation period, were performed at 2 selected temperatures, 15 and $25^{\circ} \mathrm{C}$.

Inspection and sampling of fish. All tanks were inspected daily for dead or moribund fish or any other abnormal signs. Dead fish were collected, identified by date and tank number, and submitted to the laboratory for immediate virus re-isolation, or they were frozen at $-20^{\circ} \mathrm{C}$ until they were processed. Moribund specimens were euthanized with an overdose of tricaine methanesulfonate (MS-222) and then prepared for laboratory procedures. Spleen, kidney, heart and brain, considered to be suitable tissues for the isolation of ranavirus agents (Ariel et al. 2009), were collected from each specimen and combined in a single pooled sample.

Fish challenged with ECV-24 isolate were necropsied to detect presence of macroscopic lesions before processing for virus detection. At Day 30 postchallenge, all surviving fish were euthanized with an overdose of MS-222; after euthanasia tissues from 5 or 10 fish were pooled and processed for virus examination. The observation period for the fish challenged with EHNV at $15^{\circ} \mathrm{C}$ was prolonged to $40 \mathrm{~d}$ because of the late appearance of mortality (i.e. starting at Day 22 post-challenge).

Virus re-isolation. To confirm that deaths occurring after challenge were actually due to viral infection, and not to any concurrent disease or other problems, virus reisolation was performed on dead and/or moribund fish. According to the established protocol, pooled samples were used, each consisting of a maximum of 5 fish collected on the same day from the same infected group.

Target tissues from thawed or fresh fish were homogenised with a mortar, pestle and sterile quartz. After homogenisation, tissues were diluted 1:10 with EMEM and centrifuged for $15 \mathrm{~min}$ at $4000 \times g$ at $4^{\circ} \mathrm{C}$. The supernatants were supplemented with an antibioticantimycotic solution (10\%) (Sigma-Aldrich) and Kanamycin sulphate solution (0.4\%) (Sigma-Aldrich) and were stored overnight at $4^{\circ} \mathrm{C}$.

The following day, $100 \mu \mathrm{l}$ of each sample was inoculated in $24 \mathrm{~h}$ old EPC cell monolayers grown in 24-well plates at 2 final dilutions, corresponding to 1:100 and $1: 1000$ with regard to fish tissues. After inoculation, the cell cultures were incubated at $25 \pm 2{ }^{\circ} \mathrm{C}$ for $1 \mathrm{wk}$ and inspected daily for cpe. If cpe was not observed, a blind virus sub-cultivation was started on new EPC monolayers, and the cell cultures were monitored for another $7 \mathrm{~d}$. If no cpe appeared, the samples were considered negative.

Immunofluorescent antibody technique. To confirm that the cpe obtained from moribund or dead fish samples was due to the experimental infectious agents and to rule out any cpe due to other piscine viruses or toxic effects, all samples showing cpe in cell cultures were subjected to examination by means of the immunofluorescent antibody technique (IFAT). A classic indirect method that used a hyperimmune polyclonal rabbit serum produced against the ECV isolate 562/92 was adopted. This serum has reacted with all of the ranavirus isolates tested to date (results not shown), except for DFV and GV6, which are isolates of the Santee Cooper virus. The rabbit polyclonal serum was also tested for specificity with other common piscine viruses, in particular, VHS (Viral haemorrhagic septicemia), IHN (Infectious haematopoietic necrosis) and IPN (Infectious pancreatic necrosis), without any crossreaction (authors' unpubl. data).

The original cell monolayers were examined for cpe, and $0.2 \mathrm{ml}$ was inoculated at 2 dilutions (1:1 and 1:10) into 2 actively growing EPC monolayers on 24-well plates, on which circular cover slips had been previously placed.

Positive and negative controls, which consisted of ECV (562/92 isolate) and EMEM, respectively, were included in each test. The inoculated monolayers were incubated at $20^{\circ} \mathrm{C}$. After $60 \mathrm{~min}$, each well was covered with $1 \mathrm{ml}$ EMEM containing antibiotic (as reported in the previous 
section), reduced FCS ( $2 \%$ ) and $0.8 \%$ carboxymethylcellulose sodium salt (Sigma-Aldrich). The cultures were then incubated at $20^{\circ} \mathrm{C}$ for $48 \mathrm{~h}$. After virus replication, the supernatant was removed and the monolayers were fixed with acetone solution (80\% in phosphate-buffered saline, PBS) for $30 \mathrm{~min}$. The monolayers were rinsed 3 times with PBS-Tween solution $(0.05 \%)$ and allowed to dry. For each culture, $50 \mu \mathrm{l}$ of the antibody (polyclonal rabbit anti-ECV, isolate 562/92) at a final dilution of 1:800 was added to each well and incubated at $37^{\circ} \mathrm{C}$ for 30 min. Monolayers were then rinsed 3 times with PBSTween solution $(0.05 \%)$ and allowed to dry.

In the second step, $50 \mu$ of secondary conjugated antibody (goat anti-rabbit IgG-FITC, Sigma-Aldrich) at a 1:100 final dilution was added to each well and incubated at $37^{\circ} \mathrm{C}$ for $30 \mathrm{~min}$. Finally, the monolayers were rinsed 3 times with PBS-Tween solution $(0.05 \%)$. The cover slips with stained monolayers were removed from the bottom of the wells and mounted on microscope slides with the cell side downwards in a drop of buffered glycerol (50\% in PBS 0.01M). The samples were observed at $40 \times$ magnification with an Axioscope microscope (Zeiss) equipped with an epifluorescence system (HBO $100 \mathrm{~W}$ short arc mercury lamp).

\section{RESULTS}

During the quarantine period, no clinical signs were observed and no significant pathogens were detected from randomly sampled fish. A significant mortality rate was recorded in fish challenged with ECV isolate 24/06 (Fig. 1). Similar results, though with a lower mortality, were observed in fish challenged with EHNV (Fig. 2). No significant mortality was observed for fish exposed to the remaining ranavirus isolates, as reported for ESV (Fig. 3). The percent cumulative mortalities and the results of the re-isolation tests are reported in Table 2. In the ECV challenge, the incuba-



Fig. 1. Ameiurus melas. Percent cumulative mortality observed in fish challenged in duplicate tanks with European catfish virus (ECV) isolate $24 / 06$ at 15 and $25^{\circ} \mathrm{C}$ and 2 negative controls for 15 and $25^{\circ} \mathrm{C}$, respectively (Expt 1)

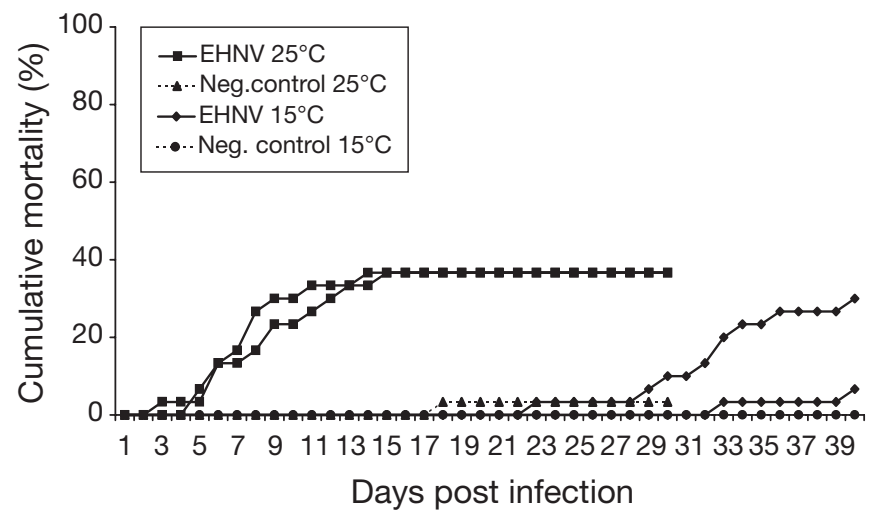

Fig. 2. Ameiurus melas. Percent cumulative mortality observed in fish challenged with epizootic haematopoietic virus (EHNV) in duplicate tanks at 15 and $25^{\circ} \mathrm{C}$ and 2 negative controls for 15 and $25^{\circ} \mathrm{C}$, respectively (Expts 2 and 3)

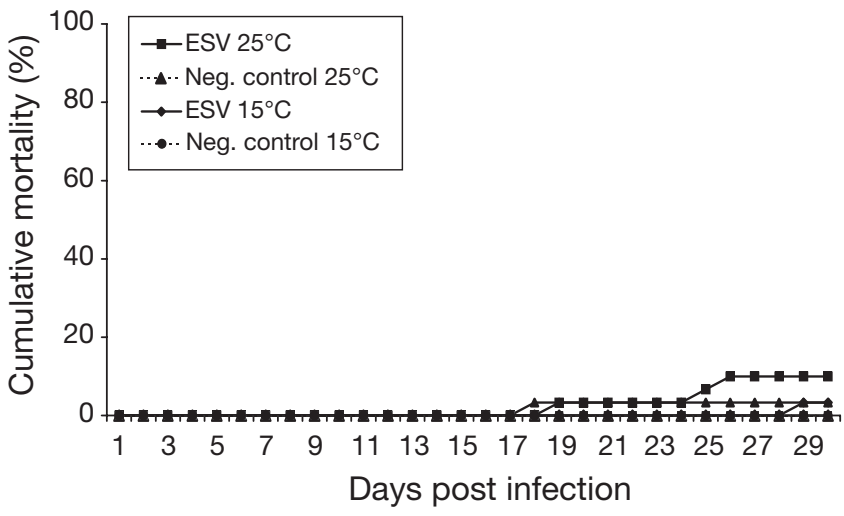

Fig. 3. Ameiurus melas. Percent cumulative mortality observed in fish challenged with European sheatfish virus (ESV) in duplicate tanks at 15 and $25^{\circ} \mathrm{C}$ and 2 negative controls for 15 and $25^{\circ} \mathrm{C}$, respectively (Expts 2 and 3)

tion periods were clearly influenced by the temperature; in particular, the incubation period was 3 to $5 \mathrm{~d}$ at $25^{\circ} \mathrm{C}$ and 10 to $12 \mathrm{~d}$ at $15^{\circ} \mathrm{C}$.

In both the ECV-challenged and EHNV-challenged groups, moribund and dead fish showed characteristic external lesions consisting of haemorrhagic petechiae on the skin and fin suffusions. During the preagonic stage, moribund fish often assumed a vertical 'candle' position, with the head above the water surface. Clinical symptoms lasted from 6 to $10 \mathrm{~d}$, and mortality was very low throughout the study. Necropsy performed on dead and moribund fish challenged with ECV isolate 24/06 showed several macroscopic lesions, including hepato-splenomegaly, hypertrophy of the anterior kidney and diffuse congestion of internal organs. Multifocal miliary and whitish lesions were observed in the spleen and kidney, whereas vascular lesions, such as petechiae and haemorrhages, occurred mainly in liver 
Table 2. Percent cumulative mortality by type of virus used for challenge at 15 and $25^{\circ} \mathrm{C}$ (values for each duplicate are given in parentheses) and number of pools in which the representive virus was re-isolated from dead or surviving fish, respectively, and the number of pools in each case. Number of fish in each duplicate tank was 30

\begin{tabular}{|c|c|c|c|c|c|}
\hline Group & $\begin{array}{l}\text { Fish age } \\
\quad(\mathrm{mo})\end{array}$ & Temperature & $\begin{array}{l}\text { Mean cumulative } \\
\text { mortality (\%) } \\
\text { (2 duplicates) }\end{array}$ & $\begin{array}{l}\text { No. of pools with } \\
\text { re-isolation from } \\
\text { dead fish/total no. } \\
\text { of pools tested }\end{array}$ & $\begin{array}{l}\text { No. of pools with } \\
\text { re-isolation from } \\
\text { surviving fish/total } \\
\text { no. of pools tested }\end{array}$ \\
\hline \multicolumn{6}{|l|}{ Expt 1} \\
\hline ECV-24/06 & 3 & $25^{\circ} \mathrm{C}$ & $82.90(82.50,83.33)$ & $16 / 18$ & $0 / 2^{\mathrm{a}}$ \\
\hline Negative control & 3 & & $2.08(0.00,4.17)$ & $0 / 1$ & $0 / 12^{\mathrm{a}}$ \\
\hline ECV-24/06 & 3 & $15^{\circ} \mathrm{C}$ & $30.00(20.00,40.00)$ & $15 / 15$ & $3 / 4^{\mathrm{b}}$ \\
\hline Negative control & 3 & & $0.00(0.00,0.00)$ & $0 / 0$ & $0 / 6^{\mathrm{b}}$ \\
\hline \multicolumn{6}{|l|}{ Expt 2} \\
\hline ESV & 6 & $25^{\circ} \mathrm{C}$ & $5.00(0.00,10.00)$ & $0 / 2$ & $0 / 10^{a}$ \\
\hline EHNV & 6 & & $36.60(36.60,36.60)$ & $17 / 18$ & $0 / 8^{a}$ \\
\hline SERV & 6 & & $1.65(0.00,3.30)$ & $0 / 0$ & $0 / 12^{\mathrm{a}}$ \\
\hline FV3 & 6 & & $0.00(0.00,0.00)$ & $0 / 0$ & $0 / 12^{\mathrm{a}}$ \\
\hline REV-like & 6 & & $3.30(0.00,6.60)$ & $0 / 2$ & $0 / 11^{a}$ \\
\hline BIV & 6 & & $0.00(0.00,0.00)$ & $0 / 0$ & $0 / 12^{\mathrm{a}}$ \\
\hline Negative control & 6 & & $1.65(0.00,3.30)$ & $0 / 0$ & $0 / 12^{\mathrm{a}}$ \\
\hline \multicolumn{6}{|l|}{ Expt 3} \\
\hline ESV & 3 & $15^{\circ} \mathrm{C}$ & $1.65(0.00,3.30)$ & $1 / 1$ & $1 / 6^{b}$ \\
\hline EHNV & 3 & & $18.30(6.60,30.00)$ & $6 / 6$ & $5 / 5^{b}$ \\
\hline SERV & 3 & & $1.65(0.00,3.30)$ & $0 / 0$ & $0 / 6^{b}$ \\
\hline FV3 & 3 & & $3.30(0.00,6.60)$ & $1 / 2$ & $0 / 6^{b}$ \\
\hline REV-like & 3 & & $0.00(0.00,0.00)$ & $0 / 0$ & $0 / 6^{b}$ \\
\hline BIV & 3 & & $0.00(0.00,0.00)$ & $0 / 0$ & $0 / 12^{\mathrm{a}}$ \\
\hline Negative control & 3 & & $0.00(0.00,0.00)$ & $0 / 0$ & $0 / 6^{\mathrm{b}}$ \\
\hline
\end{tabular}

parenchyma. No significant mortality was observed in the negative control groups.

\section{Virus re-isolation}

The results of virus re-isolation from dead or moribund fish and surviving fish are reported in Table 2. Virus re-isolation was consistently obtained only from fish challenged with ECV (isolate 24/06) and EHNV, and the re-isolation rate was different when comparing $\mathrm{dead} / \mathrm{moribund}$ and surviving fish. No virus re-isolation was obtained from fish challenged with BIV, SERV or rana esculenta-like (REV-like) virus. ESV was reisolated only from 1 dead fish and from 1 pool of surviving fish that were challenged at $15^{\circ} \mathrm{C}$, whereas FV3 was re-isolated only from 1 dead fish at $15^{\circ} \mathrm{C}$. None of the pools from the negative controls tested positive.

The appearance of the cpe was usually observed 3 to 4 $\mathrm{d}$ after EPC inoculation at $25^{\circ} \mathrm{C}$. The cpe appeared as distinct plaques of cell lysis with dense margins consisting of rounded and granular cells, which showed a strong refractivity in vivo. In 4 to $5 \mathrm{~d}$, these foci of cell lysis affected the whole cell monolayer. After staining with haematoxilin and eosin (H\&E), characteristic foci of cell lysis with thickened margins were evident (Fig. 4).

\section{IFAT Results}

All samples showing clear cpe during virus re-isolation were examined using IFAT and all showed a strong positive reaction. The positive signal, which was very similar in all of the samples tested, consisted of brilliant green granules of different sizes, mainly located in the cytoplasm of infected cells (Fig. 5). No positive reaction was observed in negative control slides.

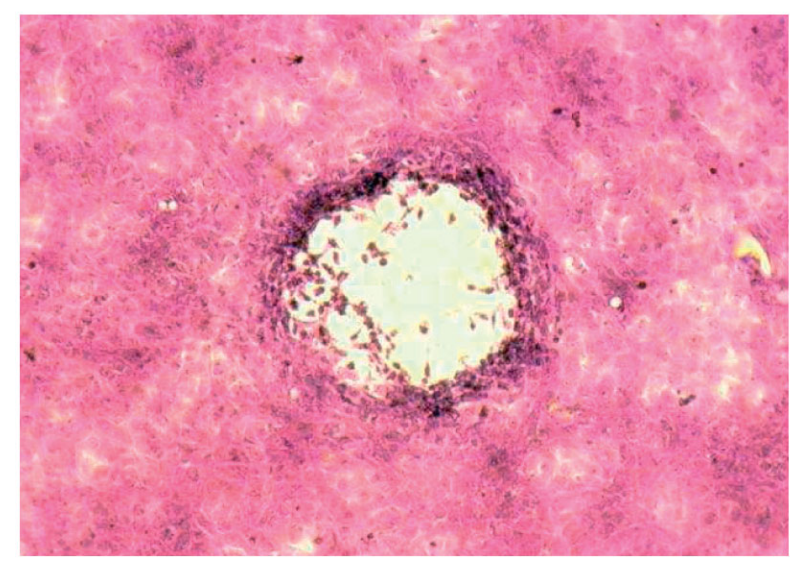

Fig. 4. Typical cytopathic effect (CPE) induced by ranaviruses on epithelioma papulosum cyprini (EPC) cells (48 h p.i.). H\&E stain 


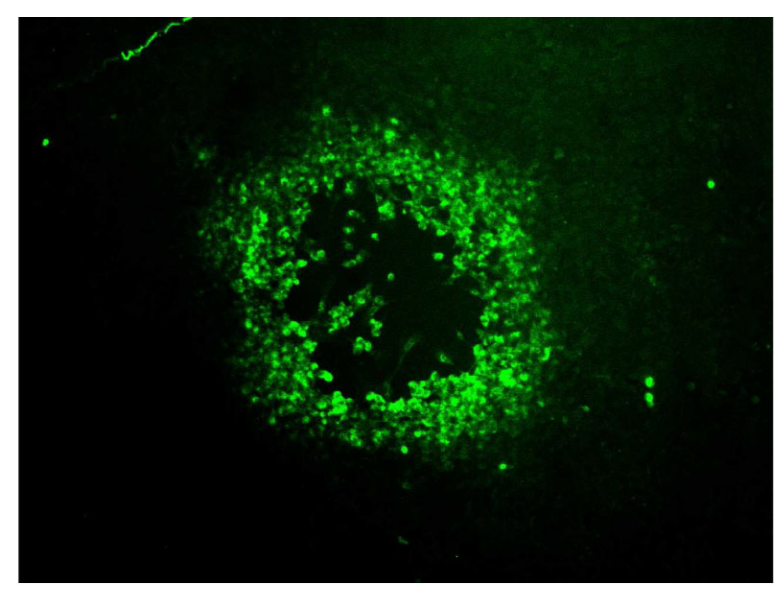

Fig. 5. Positive immunofluorescence antibody technique (IFAT) reaction with polyclonal rabbit anti-ECV, isolate $562 / 1992$, at $48 \mathrm{~h}$ post infection

\section{DISCUSSION}

The results of this study demonstrate the susceptibility of black bullhead to ECV and EHNV. Significant mortality was observed following their exposure to ECV (isolate 24/06), both at 15 and $25^{\circ} \mathrm{C}$ (Fig. 1). The highest mortality $(82.9 \%)$ was reached more rapidly at $25^{\circ} \mathrm{C}$. At $15^{\circ} \mathrm{C}$, the final mortality was lower $(30 \%)$ than that at $25^{\circ} \mathrm{C}$, and the first clinical signs appeared $10 \mathrm{~d}$ later, possibly because of a less active replication of the causal agent in the host tissues, as demonstrated by in vitro experiments (Ariel et al. 2009). Given that the observations were stopped at $30 \mathrm{~d}$ post injection (p.i.), we cannot exclude the possibility that mortality could increase in groups maintained at $15^{\circ} \mathrm{C}$, in which several survivors were found to be virus positive. The finding that infection occurs in such a wide temperature range is not surprising, in that it reflects the range which occurs under natural conditions. In fact, most natural outbreaks of ECV infection are detected during the summer at temperatures of 22 to $25^{\circ} \mathrm{C}$ or higher, but on some occasions infection has been observed during the winter at 11 to $15^{\circ} \mathrm{C}$. Similar seasonal findings were reported for EHN in Australia, where natural outbreaks in redfin perch tend to occur during the summer (Langdon et al. 1986, Langdon \& Humphrey 1987, Whittington et al. 1994). The influence of temperature on the pathogenesis of viral infection has been well documented for several fish diseases.

Surprisingly, no significant mortality was detected for fish challenged with ESV (Fig. 3). This virus is closely related to ECV, at least from a molecular point of view (Hyatt et al. 2000), and according to the current taxonomy it is considered to be a different isolate of the same species
(Fauquet et al. 2005). After challenge, ESV was indeed re-isolated from 1 dead specimen and from surviving fish in 1 out of 6 tissue pools tested at $15^{\circ} \mathrm{C}$, but no virus reisolation was obtained from dead or surviving fish maintained at $25^{\circ} \mathrm{C}$. The failure of ESV to induce significant mortality could be explained by a possible decrease of in vivo pathogenicity due to repeated in vitro subcultures. However, the same virus isolate was tested in another laboratory participating in the same project and was shown to induce a significant mortality in the original target host Silurus glanis, which was exposed to the same conditions to which Ameiurus melas was exposed (S. Bergman pers. comm.). For this reason, if we exclude the possibility of reduced pathogenicity of the isolate used in our study, we could suppose that ESV, though genetically very similar to ECV, could contain minor differences as demonstrated by restriction enzyme analysis (Holopainen et al. 2009), which would result in this virus having different pathogenicity features. Further investigations should be performed to definitively understand their taxonomy.

Significant mortality was observed in fish challenged with EHNV at $25^{\circ} \mathrm{C}$ and, to a lesser extent, in those challenged at $15^{\circ} \mathrm{C}$ (Fig. 2). This represents the first finding of the susceptibility of Ameiurus melas to EHNV infection associated with typical ranavirus lesions and mortality, supporting the systemic nature of ranavirus infection and the strong virus tropism for haematopoietic tissue. Because of the potential consequences on animal health, it is important that additional studies be performed to confirm these findings. EHN is a listed disease according to the World Organisation for Animal Health (OIE 2009a) and is considered exotic to the European Union (Council of the European Union 2006). To reduce the risk of its spread, it would thus be necessary to include A. melas on the list of EHN-susceptible species.

The mortality recorded at $25^{\circ} \mathrm{C}$ was higher than that observed at $15^{\circ} \mathrm{C}$, despite the fact that older fish, which are considered to be more resistant, were employed. This finding supports the high-temperature tropism of EHNV and its seasonable features in natural outbreaks in Australia (Langdon \& Humphrey 1987, Whittington \& Reddacliff 1995).

The infection trial performed at $15^{\circ} \mathrm{C}$ was prolonged to $40 \mathrm{~d}$ p.i. because of the appearance of late mortality at Day 22 p.i. Similar findings were reported by Whittington \& Reddacliff (1995) in redfin perch exposed to EHNV at 2 different temperatures. At $15^{\circ} \mathrm{C}$, EHNV was re-isolated from all tissue pools tested from dead fish (6 out of 6) and from surviving fish (5 out of 5) maintained at the same temperature and tested $40 \mathrm{~d}$ p.i. These results are slightly different from the results obtained when testing surviving fish maintained at $25^{\circ} \mathrm{C}$, in which none of the 8 pools tested were positive. 
The virus re-isolation in surviving fish tested positive only for fish challenged with ECV, EHNV and ESV and only for those maintained at $15^{\circ} \mathrm{C}$, whereas there was no positive virus re-isolation for fish maintained at $25^{\circ} \mathrm{C}$. These results are probably due to a less efficient immune response at low temperatures, which could permit the virus to escape the immune competent cells and persist for a longer period in target tissues. In fact, it is well known that temperature has an effect on specific immune responses (Avtalion 1969, Avtalion et al. 1970, Rijkers 1981, Hardie et al. 1994, Watson et al.1998). The occurrence of infection at a low temperature may be responsible for sub-chronic conditions, as described in white sturgeon Acipenser transmontanus experimentally infected with white sturgeon iridovirus (Watson et al. 1998).

The failure of virus re-isolation in surviving fish maintained at $25^{\circ} \mathrm{C}$, which represents the optimal replication temperature for most of the selected ranaviruses (Ariel et al. 2009) including ECV, is probably due to the optimal immune response conditions at this temperature, which can neutralize residual virus particles in the host at the end of the clinical phase. These results indicate that carrier status may depend on water temperature, with this status lasting for a shorter period at high temperatures. This information could be useful for decision-making authorities when quarantine programs have to be implemented. Our results suggest that fish surviving EHNV infection may recover more rapidly at $25^{\circ} \mathrm{C}$ than at $15^{\circ} \mathrm{C}$, at least in the case of Ameiurus melas.

The susceptibility of this species to ECV (isolate 24/06) and EHNV, both of which induce similar clinical signs and lesions, demonstrates the need for a differential diagnosis. Unfortunately, because ranaviruses share common epitopes (Ahne et al. 1995), and specific neutralizing monoclonal antibodies are unavailable, it has not been possible so far to serologically distinguish among Ranavirus species; thus, there is an urgent need to adopt the existing molecular tools (Marsh et al. 2002, Holopainen et al. 2009). According to OIE (2009b), the combined use of 2 different PCR assays using primers for the major capsid protein $(\mathrm{MCP})$, followed by restriction analysis, may allow EHNV to be detected and differentiated from the European (ECV), North American (FV3) and other Australian ranaviruses (BIV).

In our study, a rabbit polyclonal antibody produced against ECV isolate 152/92, which recognizes all of the ranaviruses tested, except GV-6 and DFV, was used to identify the re-isolated viruses obtained from dead/ moribund or surviving fish. However, the test allowed us to identify ranavirus isolates only at the genus level.

According to our results, the black bullhead seems to be completely resistant to SERV, BIV, REV-like and to
FV3, though in the latter case virus re-isolation was obtained from 1 dead fish infected at $15^{\circ} \mathrm{C}$.

During re-isolation testing, the cpe usually appeared at 3 to $4 \mathrm{~d}$ post-EPC inoculation at $25^{\circ} \mathrm{C}$. All cpe-positive samples obtained from virus re-isolation and submitted to IFAT showed a strong positive reaction. No cross-reaction was observed with different viruses used as negative controls (IHNV, IPNV and VHSV). In addition to the susceptibility of Ameiurus melas to EHNV infection and the correlation between mortality and temperature, the results of our study confirmed, under controlled conditions, the high pathogenicity of ECV to A. melas. This pathogenicity is difficult to demonstrate in field conditions where concurrent bacterial infections are often detected which may confound the clinical picture and make it difficult to understand the effect of individual pathogens.

Acknowledgements. The present study has been granted under the 6th framework program of the European Union research project RANA, no. SSPE-CT-2005-006459 'Risk assessment of new and emerging systemic iridoviral diseases for European fish and aquatic ecosystems'. The National Veterinary Institute of Denmark, Aarhus, served as the project leader and supplied the selected isolates. The authors thank R. Whittington (University of Sydney, Australia), W. Ahne (University of Munich, Germany) and A. Hyatt (Australian Animal Health Laboratory, Victoria, Australia), for providing some of the isolates used in the study. Special thanks is extended to R. Quartesan and P. Giacometti for their skilful technical assistance, and F. Borghesan for invaluable advice regarding the black bullhead experiments.

\section{LITERATURE CITED}

Ahne W, Schlotfeldt HJ, Thomsen I (1989) Fish viruses: isolation of an icosahedral cytoplasmatic deoxyribovirus from sheatfish (Silurus glanis). J Vet Med 36:333-336

Ahne W, Matazin Z, Bovo G (1995) Antigenic relationship of epizootic haematopoietic necrosis virus (EHNV) and iridovirus-like isolates from European green frogs (Rana esculenta). Bull Eur Assoc Fish Pathol 15:142-144

Ariel E, Nicolajsen N, Christophersen MB, Holopainen R, Tapiovaara H, Jensen BB (2009) Propagation and isolation of ranaviruses in cell culture. Aquaculture 294:159-164

Ariel E, Owens L (1997) Epizootic mortalities in tilapia Oreochromis mossambicus. Dis Aquat Org 29:1-6

Avtalion RR (1969) Temperature effect on antibody production and immunological memory in carp (Cyprinus carpio) immunized against bovine serum albumin (BSA). Immunology 17:927-931

Avtalion RR, Malik Z, Lefler E, Katz E (1970) Temperature effect on immune resistance of fish to pathogens. Bamidgeh Bull Fish Cult Isr 22:33-38

Bang Jensen B, Kjear Ersbøll A, Ariel E (2009) Susceptibility of pike Esox lucius to a panel of Ranavirus isolates. Dis Aquat Org 83:169-179

Bigarré L, Cabon J, Baud M, Pozet F, Castric J (2008) Ranaviruses associated with high mortalities in catfish in France. Bull Eur Assoc Fish Pathol 28:163-168

$>$ Bloch B, Larsen JL (1993) An iridovirus-like agent associated with systemic infection in cultured turbot Scophthalmus 
maximus fry in Denmark. Dis Aquat Org 15:235-240

Bollinger TK, Mao J, Shock D, Brigham RM, Chinchar VC (1999) Pathology, isolation and molecular characterization of an iridovirus from tiger salamanders in Saskatchewan. J Wildl Dis 35:413-429

Bovo G, Comuzzi M, De Mas S, Ceschia G, Giorgetti G, Giacometti P, Cappellozza E (1993) Isolation of an irido-like viral agent from breeding cat fish (Ictalurus melas). Boll Soc It Patol Ittica 11:3-10

Bovo G, Giacometti G, Montesi F, Cappellozza E, Ormelli S (1999) Isolation of an irido-like viral agent from New Zealand eel. In: 9th International Conference of European Association of Fish Pathologists, Rhodes, p 153 (Abstract)

Chinchar VG, Essbauer S, He JG, Hyatt A, Mijyaki T, Seligri V, Williams T (2005) Family Iridoviridae. In: Fauquet CM, Mayo MA, Maniloff J, Desselberger U, Gall LA (eds) Virus taxonomy. 8th Report of the International Committee on Taxonomy of Viruses. Elsevier, London, p 145-162

Commission of the European Communities (2001) Commission Decision 2001/183/EC of 22 February 2001 laying down the sampling plans and diagnostic methods for the detection and confirmation of certain fish diseases and repealing Decision 92/532/EEC. Off J Eur Communities L67:65-76

Council of the European Union (2006) Council Directive 2006/88/EC of 24 October 2006 on animal health requirements for aquaculture animals and products thereof, and on the prevention and control of certain diseases in aquatic animals. Off J Eur Union L328:14-56

Cullen BR, Owens L (2002) Experimental challenge and clinical cases of Bohle iridovirus (BIV) in native Australian anurans. Dis Aquat Org 49:83-92

Cunningham AA, Tems CA, Russell PH (2008) Immunohistochemical demonstration of ranavirus antigen in the tissues of infected frogs (Rana temporaria) with systemic haemorrhagic or cutaneous ulcerative disease. J Comp Pathol 138:3-11

Duffus ALJ, Pauli BD, Wozney $\mathrm{K}$, Brunette CR, Berrill M (2008) Frog virus 3-like infections in aquatic amphibian communities. J Wildl Dis 44:109-120

Fauquet CM, Mayo MA, Maniloff J, Desselberger U, Ball LA (2005) Virus taxonomy. 8th Report of the International Committee on Taxonomy of Viruses. Elsevier, London

Gantress J, Bell A, Manoiero G, Cohen N, Robert J (2003) Xenopus, a model to study immune responses to iridovirus. Virology 311:254-262

Gibson-Kueh S, Netto P, Ngoh-Lim GH, Chang SF and others (2003) The pathology of systemic iridoviral disease in fish. J Comp Pathol 129:111-119

Granoff A, Came PE, Breeze DC (1966) Viruses and renal carcinoma of Rana pipiens. I. Isolation and properties of virus from normal and tumor tissue. Virology 29:133-148

> Green DE, Converse KA, Schraeder AK (2002) Epizootiology of sixty-four amphibian morbidity and mortality events in the USA, 1996-2001. Ann NY Acad Sci 969:323-339

> Hardie LJ, Fletcher TC, Secombes CJ (1994) Effect of temperature on macrophage activation and the production of macrophage activating factor by rainbow trout leucocytes. Dev Comp Immunol 18:57-66

Holopainen R, Ohlemeyer S, Schütze H, Bergman SM, Tapiovaara H (2009) Ranavirus phylogeny and differentiation based on major capsid protein, DNA polymerase and neurofilament triplet H1-like protein genes. Dis Aquat Org 85:81-91

- Hyatt AD, Gould AR, Zupanovic Z, Cunningham AA and others (2000) Comparative studies of piscine and amphibian iridovirus. Arch Virol 145:301-331

Jancovich JK, Davidson EW, Morado JF, Jacobs BL, Collins JP

Editorial responsibility: Andrew Cunningham,

London, UK
(1997) Isolation of a lethal virus from endangered tiger salamander Ambystoma tigrinum stebbinsi. Dis Aquat Org 31:161-167

> Langdon JS (1989) Experimental transmission and pathogenicity of epizootic haematopoietic necrosis virus (EHNV) in redfin perch, Perca fluviatilis L., and 11 other teleosts. J Fish Dis 12:295-310

- Langdon JS, Humphrey JD (1987) Epizootic haematopoietic necrosis, a new viral disease in redfin perch, Perca fluviatilis L., in Australia. J Fish Dis 10:289-297

> Langdon JS, Humphrey JD, Williams LM, Hyatt AD, Westbury HA (1986) First virus isolation from Australian fish: an iridovirus-like pathogen from redfin perch, Perca fluviatilis L. J Fish Dis 9:263-268

Langdon JS, Humphrey JD, Williams LM (1988) Outbreaks of an EHNV-like iridovirus in cultured rainbow trout, Salmo gairdneri Richardson, Australia. J Fish Dis 11:93-96

- Marsh IB, Whittington RJ, O'Rourke B, Hyatt AD, Chisholm O (2002) Rapid differentiation of Australian, European and American ranaviruses based on variation in major capsid proteine sequence. Mol Cell Probes 16:137-151

> Moody NJG, Owens L (1994) Experimental demonstration of the pathogenicity of a frog virus, Bohle iridovirus, for a fish species, barramundi Lates calcarifer. Dis Aquat Org 18: 95-102

Nakajima K, Maeno Y (1998) Pathogenicity of red sea bream iridovirus and other iridoviruses to red sea bream. Fish Pathol 33:143-144

OIE (World Organisation for Animal Health) (2009a) Chapter 1.3. In: Aquatic Animal Health Code, 12th edn. World Organisation for Animal Health, Paris, p 7-8

OIE (World Organisation for Animal Health) (2009b). Chapter 2.3.1. Epizootic haematopoietic necrosis. In: Manual of diagnostic tests for aquatic animals. World Organisation for Animal Health, Paris, p 168-187

Pozet F, Morand M, Moussa A, Torhy C, de Kinkelin P (1992) Isolation and preliminary characterization of a pathogenic icosahedral deoxyribovirus from the catfish Ictalurus melas. Dis Aquat Org 14:35-42

Rijkers GT (1982) Kinetics of humoral and cellular immune reactions in fish. Dev Comp Immunol(Suppl) 2:93-100

Speare R, Smith JR (1992) An iridovirus-like agent isolated from the ornate burrowing frog Limodynastes ornatus in northern Australia. Dis Aquat Org 14:51-57

Tapiovaara H, Olesen NJ, Lindén J, Rimaila-Pärnänen E, von Bonsdorff $\mathrm{CH}$ (1998) Isolation of an iridovirus from pikeperch Stizostedion lucioperca. Dis Aquat Org 32:185-193

- Watson LR, Milani A, Hedrick RP (1998) Effects of water temperature on experimentally-induced infections of juvenile white sturgeon (Acipenser transmontanus) with the white sturgeon iridovirus (WSIV). Aquaculture 166: $213-228$

- Whittington RJ, Reddacliff GL (1995) Influence of environmental temperature in experimental infection of redfin perch (Perca fluviatilis) and rainbow trout (Oncorhynchus mykiss) with epizootic haematopoietic necrosis virus, an Australian iridovirus. Aust Vet J 72:421-424

Whittington RJ, Philbey A, Reddacliff GL, Macgown AR (1994) Epidemiology of epizootic haematopoietic necrosis virus (EHNV) infection in farmed rainbow trout, Oncorhynchus mykiss (Walbaum): findings based on virus isolation, antigen capture ELISA and serology. J Fish Dis 17:205-218

Williams T, Barbosa-Solomieu V, Chinchar VG (2005) A decade of advances in iridovirus research. Adv Virus Res 65:173-248

Wolf K, Bullock G, Dunbar C, Quimby M (1968) Tadpole edema virus: viscerotropic pathogen for anuran amphibians. J Infect Dis 118:253-262 